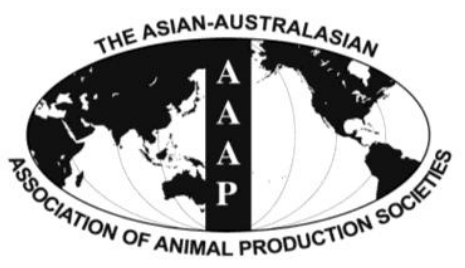

Asian-Aust. J. Anim. Sci.

Vol. 25, No. 7 : 935 - 944

July 2012

www.ajas.info

http://dx.doi.org/10.5713/ajas.2011.11500

\title{
Phylogeography and Population Genetic Structure of Amur Grayling Thymallus grubii in the Amur Basin
}

\author{
Bo Ma, Tingting Lui ${ }^{1}$, Ying Zhang and Jinping Chen ${ }^{1, *}$ \\ Heilongjiang River Fisheries Research Institute, Chinese Academy of Fishery Sciences, Harbin 150070, China
}

\begin{abstract}
Amur grayling, Thymallus grubii, is an important economic cold freshwater fish originally found in the Amur basin. Currently, suffering from loss of habitat and shrinking population size, T. grubii is restricted to the mountain river branches of the Amur basin. In order to assess the genetic diversity, population genetic structure and infer the evolutionary history within the species, we analysised the whole mitochondrial DNA control region (CR) of 95 individuals from 10 rivers in China, as well as 12 individuals from Ingoda/Onon and Bureya River throughout its distribution area. A total of 64 variable sites were observed and 45 haplotypes were identified excluding sites with gaps/missing data. Phylogenetic analysis was able to confidently predict two subclade topologies well supported by maximum-parsimony and Bayesian methods. However, basal branching patterns cannot be unambiguously estimated. Haplotypes from the mitochondrial clades displayed local homogeneity, implying a strong population structure within T. grubii. Analysis of molecular variance detected significant differences among the different geographical rivers, suggesting that $T$. grubii in each river should be managed and conserved separately. (Key Words: Amur Grayling, Population Genetic Structure, Phylogeography, Mitochondrial DNA Control Region)
\end{abstract}

\section{INTRODUCTION}

Dispersal ability is a key demographic force shaping natural populations and maintaining evolutionary potential (Proctor et al., 2004). Species with limited dispersal abilities display clearer population genetic structure but lower genetic diversity than do species with a tendency towards greater dispersal (Kark et al., 1999; Garcia-Ramos et al., 1999; Bailey et al., 2007). The populations of freshwater fish species from different river systems often show significant genetic differentiation resulting from restricted gene flow, and also there is evidence that some species show high levels of genetic differentiation between populations within a river system (McGlashan et al., 2000). Consequently, changes in interconnectivity within and between drainages have greatly influenced the distribution of many fish species and their genetic structure.

Northeast China has a special and old complex animal fauna and high biodiversity. Based on the geographic distribution, origin and evolution of fishes, there are six

\footnotetext{
* Corresponding Author: Jinping Chen. Tel: +86-20-84183704, Fax: +86-20-89100920, E-mail: chenjp@gdei.gd.cn

${ }^{1}$ Guangdong Entomological Institute/South China Institute of Endangered Animals, Guangzhou, 510260, China.

Submitted Dec. 22, 2011; Accepted Mar. 23, 2012; Revised Apr. 3, 2012
}

zoogeographical faunal complexes in this area (Nicolsigy, 1960). In this region, Da xing an Mountain, Xiao xing an Mountain and Chang bai Mountain surround the Northeast Plain, and the five main rivers that flow through this area, Amur River, Sungari, Nenjiang, Yalu and Tumen River, have been repeatedly connected and disconnected with each other during the past million years. It has been proposed that the geological history and topographical complexity of this region would have an effect on species diversity. However, little research has focused on this area, and there is no phylogeographic studies on terrestrial vertebrates or freshwater species in this region.

Amur grayling described at the specific level as Thymallus grubii (Dybowski, 1869), have been maintained to support capture and commercial fishing in some temperate countries in the northern hemisphere, and have recently become the focus of conservation efforts in the North Pacific (Mikko et al., 2002). In China, Amur grayling is also a specific and economically important cold freshwater fish with extreme site fidelity and low dispersal capacity. It has only been recorded in the Amur basin and limited to the upper levels of some rivers, which makes the species an ideal model for the study of palaeoclimatic effects on population genetic structure and phylogeography. A recent study of $T$. grubii showed the existence of three 
diagnosable, reciprocally monophyletic, and most probably reproductively isolated lineages of grayling within the Amur drainage (Froufe et al., 2003), In this study, therefore, we examine the phylogeography of $T$. grubii and explore the possible mechanisms responsible for the current genetic pattern and to provide an insight into the historical legacy of zoogeographical faunal in Northeast China.

\section{MATERIALS AND METHODS}

Amur grayling $(\mathrm{N}=95)$ were collected in 2004-2008 from 10 localities of ten rivers distributed throughout the species' range in the Amur basin in China (Figure 1, Table 1). Based on a comment by Antonov et al. (1996), fish was first noted as to whether they had an obvious yellow-orange ocellus-like spot on the posterior edge of the dorsal fin, and to eliminate the possibility that these samples came from related individuals, we selected many patches from one location. After, a small fin clip had been preserved in $96 \%$ ethanol, whole fish were stored at -20 degrees. We also retrieved an additional 12 individual sequences collected from throughout its distribution area in the Ingoda/Onon and Bureya Rivers from GenBank (http:// www.ncbi.nlm.nih.gov/Genbank/) for evolutionary analyses. (Accession no. AY168390 AY168399, AY779010, AY779009)

\section{Mitochondrial DNA analysis}

Total genomic DNA was extracted from the tissue samples using phenol-chloroform extraction (Taggart et al., 1992). The DNA precipitate was re-suspended in TE buffer then stored at $-20^{\circ} \mathrm{C}$. The complete mitochondrial DNA (mtDNA) control region (904 base pairs) and 200 base pairs of flanking tRNA gene regions were amplified and

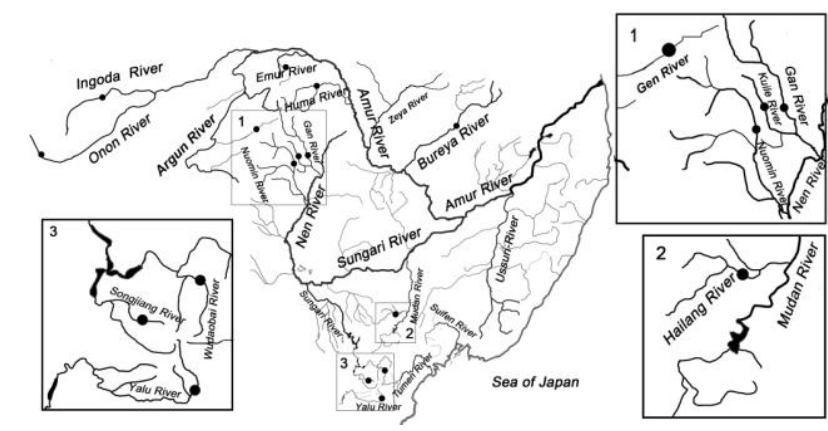

Figure 1. Sampling locations for Amur graying Thymallus grubii across whole sampling range and detailed view of sampling sites with 1,2 and 3.

sequenced. The primers were described in Uiblein et al. (2001). Amplification was performed in a total volume of $50 \mu$ containing $25 \mathrm{mM} \mathrm{MgCl} 2,10 \mathrm{mM}$ Tris- $\mathrm{HCl}, 1.5 \mathrm{mM}$ $\mathrm{Mg}^{2+}, 200 \mu \mathrm{mol}$ of each dNTP, $0.2 \mu \mathrm{mol}$ of each primer, 2.0 U Hot start Taq DNA polymerase (QIAGEN), and $\leq 10 \mathrm{ng}$ of genomic DNA. Thirty cycles were amplified on a PerkinElmer Cetus 9700 DNA thermocycler with pre denaturing at $94^{\circ} \mathrm{C}$ for $3 \mathrm{~min}$; denaturing at $94^{\circ} \mathrm{C}$ for $45 \mathrm{~s}$, annealing at $55^{\circ} \mathrm{C}$ for $45 \mathrm{~s}$, and extension at $72^{\circ} \mathrm{C}$ for $45 \mathrm{~s}$; and a final 8 min of extension at $72^{\circ} \mathrm{C}$. Positive (with DNA template) and negative (with water) controls were used to check PCR performance and contamination. The PCR products were purified using PCR purification Kit (Shanghai Bio-Tec, Ltd) and sequenced with the ABI PRISM BigDye Terminator Ready Reaction Kit (Applied Biosystems) and run on an ABI 377 genetic analyzer according to manufacturer's protocol. To avoid the errors in sequencing, PCR amplifications of all samples were sequenced for both strands.

Table 1. Sample locations including major river basin, geographical coordinates and the number of individuals analyzed for mtDNA variation

\begin{tabular}{|c|c|c|c|c|c|c|}
\hline Map no. & Population & Basin & Pop code & $\begin{array}{c}\text { No. of } \\
\text { individuals }\end{array}$ & Latitude & Longitude \\
\hline 1 & Emur River & Amur & EM & 4 & $52^{\circ} 55^{\prime}$ & $122^{\circ} 47^{\prime}$ \\
\hline 2 & Huma River & Amur & $\mathrm{HM}$ & 16 & $52^{\circ} 18^{\prime}$ & $124^{\circ} 42^{\prime}$ \\
\hline \multirow[t]{2}{*}{3} & Ingoda River* & Amur & Amu & 10 & $51^{\circ} 20^{\prime}$ & $113^{\circ} 26^{\prime}$ \\
\hline & Onon River* & & & & $48^{\circ} 75^{\prime}$ & $110^{\circ} 25^{\prime}$ \\
\hline 4 & Gen River & Amur & GE & 4 & $50^{\circ} 46^{\prime}$ & $121^{\circ} 31^{\prime}$ \\
\hline 5 & Nuomin River & Nen $\rightarrow$ Sungari $\rightarrow$ Amur & NM & 3 & $48^{\circ} 36^{\prime}$ & $124^{\circ} 07^{\prime}$ \\
\hline 6 & Kuile & Gan $\rightarrow$ Nen $\rightarrow$ Sungari $\rightarrow$ Amur & K & 3 & $49^{\circ} 32^{\prime}$ & $124^{\circ} 27^{\prime}$ \\
\hline 7 & Gan River & Nen $\rightarrow$ Sungari $\rightarrow$ Amur & $\mathrm{GH}$ & 18 & $49^{\circ} 42^{\prime}$ & $124^{\circ} 35^{\prime}$ \\
\hline 8 & Hailang River & Mudan $\rightarrow$ Sungari $\rightarrow$ Amur & HL & 19 & $44^{\circ} 28^{\prime}$ & $128^{\circ} 54^{\prime}$ \\
\hline 9 & Yalu River & Yalu & YL & 12 & $41^{\circ} 26^{\prime}$ & $128^{\circ} 12^{\prime}$ \\
\hline 10 & Songjiang River & deuto-Sungari $\rightarrow$ Sungari $\rightarrow$ Amur & SJ & 8 & $42^{\circ} 10^{\prime}$ & $127^{\circ} 30^{\prime}$ \\
\hline 11 & Wudaobai River & deuto-Sungari $\rightarrow$ Sungari $\rightarrow$ Amur & WD & 8 & $42^{\circ} 16^{\prime}$ & $128^{\circ} 25^{\prime}$ \\
\hline 12 & Bureya* & Amur & Bur & 2 & $51^{\circ} 55^{\prime}$ & $134^{\circ} 53^{\prime}$ \\
\hline
\end{tabular}

* Data is from Froufe et al. (2003a) and Froufe et al. (2003b). 


\section{Data analysis}

Sequences were aligned by using the CLUSTALX software (1.83) and visually rechecked. Haplotypes were identified using DNASP (Rozas, 2003). Pairwise sequence differences among the haplotypes were calculated using MEGA 2.1 (Kumar et al., 2001). For phylogenetic analysis, we performed maximum-parsimony (MP) using the program PAUP 4.0 (Swofford 2001) and MRBAYES 3.0 (Huelsenbeck and Ronquist, 2001). Modeltest 3.06 (Posada and Crandall, 1998) was run to determine the appropriate model of molecular evolution in a likelihood ratio test framework, and Thymallus thymallus and T. tugarinae were used as out-groups. Gaps were treated as missing in parsimony analyses. Bootstrap analyses were performed with 6,000 replicates and 1,000 full heuristic replicates for maximum parsimony. For Bayesian phylogenetic inference, four Markov chain Monte Carlo (MCMC) were run for 100,000 generations, sampling every 10 generations; the initial 5\% of trees were discarded as burn-in, finally, a 50\% majority rule consensus tree was constructed.

Genetic diversity within populations was estimated by haplotype (h) and nucleotide diversities $(\pi)$ (Nei, 1986) using DNASP (Rozas et al., 2003). Hierarchical analysis of molecular variance (AMOVA) (Excoffier et al., 1992) was performed to compare levels of genetic diversity within and among several possible population groupings of Amur grayling using Arlequin 2.0 (Schneider et al., 2000) with 1,000 permutations. The groupings that maximize values of $\emptyset_{\mathrm{CT}}$ and are statistically significant indicate the most parsimonious geographical subdivisions. Genetic differentiation between geographical subdivisions was assessed by comparing average numbers of pairwise differences between distribution ranges (PiXY); average number of pairwise differences within populations ( $\mathrm{PiX}$ and $\mathrm{PiY}$ ); and the corrected average pairwise difference (PiXY$(\mathrm{PiX}+\mathrm{PiY}) / 2)$ using Arlequin 2.0.

To test the hypothesis of demographic expansion, we used the population parameter of the program Arlequin 2.0, to compare the observed distribution of pairwise nucleotide difference among haplotypes within Amur grayling with the expectations of a sudden expansion model (Rogers and Harpending, 1992; Rogers, 1995). For populations experiencing long-term demographic stability, the stochastic process of lineage extinction via genetic drift produces a ragged multimodal distribution. Conversely, a unimodal Poisson mismatch distribution is predicted for populations that have experienced a recent demographic expansion.

Tests for departures from a neutral model of evolution are used widely to infer past demographic expansions or contractions (Ramos-Onsins and Rozas, 2002). Under a demographic expansion hypothesis, the observed pattern of sequence evolution is expected to be significantly different from that predicted under assumptions of selective neutrality and demographic equilibrium. Because we were interested in discriminating between demographic expansion and contraction, we chose two statistical tests, each with particular sensitivity to one demographic scenario. $\mathrm{Fu}$ and $\mathrm{Li}^{\prime} \mathrm{s} \mathrm{D}^{*}$ is designed to detect an excess of old mutations, characteristic of a population that has experienced a historical reduction in effective population size (Fu, 1997). In contrast, Fu's Fs is sensitive to an excess of recent mutations, a pattern typical of both a demographic expansion and a selective sweep (Fu, 1997; Ramos-Onsins and Rozas, 2002). D* was calculated in DNASP, Fs in Arlequin 2.0.

\section{RESULTS}

\section{mtDNA}

From 1,104 bp CR mtDNA sequence generated from 107 individuals, 64 variable nucleotide sites were resolved, including transversion (tv), transition (ts) and 16 insertion/ deletions, and 45 haplotypes were defined (Accession no. JF810859 JF810882, EU513355, EU513357 EU513363, EU513365 EU513368, EU513370 EU513372, AY779010, AY168391, AY168397, AY168394, AY168399, AY168396). The $\mathrm{H} 81 \mathrm{uf}+\mathrm{I}+\mathrm{G}$ model was identified using MODELTEST as the best fitting distance estimator, with a gamma distribution shape parameter of 0.7304 , a transition/ transversion $(\mathrm{Ti} / \mathrm{Tv})$ ratio of 1.8181 , and base frequencies of $\mathrm{A}=0.3281, \mathrm{C}=0.2108, \mathrm{G}=0.1460, \mathrm{~T}=0.3181$. Parsimony analyses were performed under equal weight $(\mathrm{Ti} / \mathrm{Vi}=1)$ and unequal weight $(\mathrm{Ti} / \mathrm{Vi}=1.8181)$ sets. All phylogenetic analyses resulted in almost identical tree topologies, and there was geographical structure among haplotypes related to different rivers (Figure 2), which was supported by network analysis (Figure 3).

Forty-five different haplotypes were identified in the 107 samples analyzed (Tables 2 and 3). The number of haplotypes ranged from 1 to 11 for each river. The populations with the greatest number of haplotypes were the Huma River population (11). The haplotype frequency distribution was strongly skewed, with the vast majority of haplotypes found only once (42 out of 45) and restricted to a single population. $\mathrm{H} 44$ and $\mathrm{H} 28$ were the most common haplotypes and were found in three sampled populations.

\section{Population genetic structure and phylogeography}

Diversity indices (average \pm standard deviation), $\mathrm{h}$ and $\pi$, are summarized in Table 4 . The total of $\mathrm{h}$ was $0.972 \pm 0.050$ ranging from $0.733 \pm 0.108$ in the Sungari River to 0.924 \pm 0.075 in the Amur River, and $\pi$ was $0.0081 \pm 0.0004$ ranging from $0.0012 \pm 0.0013$ to $0.0048 \pm 0.005$ in Sungari and Amur Rivers. Even when there were few samples from some rivers, the results showed a high haplotype diversity and a low nucleotide diversity, and that the genetic diversity 


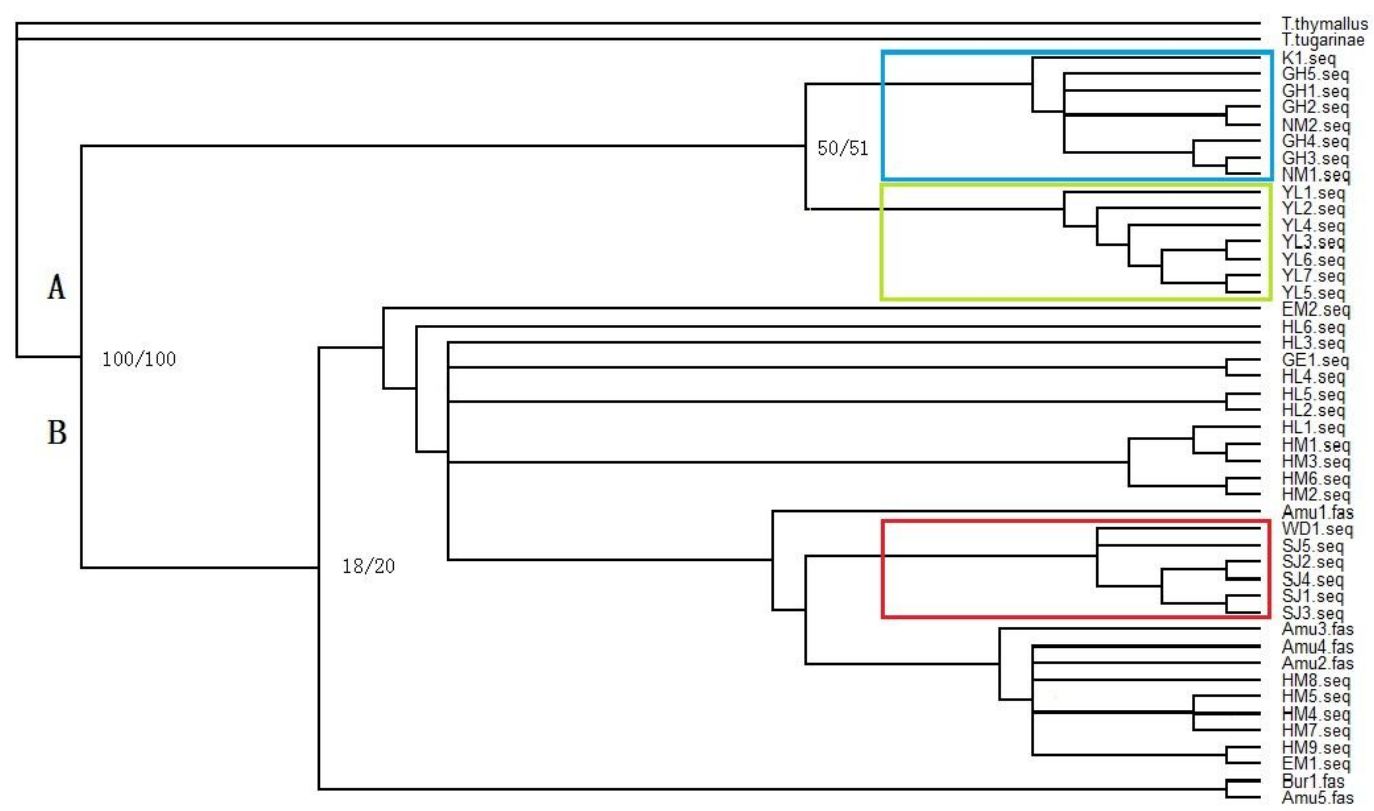

Figure 2. Phylogenetic tree obtained in Bayesian inference from the analysis of D-loop sequences with Thymallus thymallus and T. tugarinae as out-groups.

for the upper level of Amur (Ingoda/Onon, Huma, Emur and Gen Rivers) was higher than others (Table 4). Haplotypes defined by mtDNA displayed very strong geographical specificity, consistent with river clustering based on different rivers: of the 45 haplotypes, only 4 were shared among rivers. Haplotype 05 was found in both Kuile River and Gen River, Haplotype 39 was found in both Huma River and Gen River Haplotype 28, shared by 7 individuals, was found in 3 rivers (Emur, Huma, Gen Rivers), Haplotype 44, shared by 7 individuals, was found in 3 rivers (Hailang, Huma, Ingoda/Onon Rivers) (Table 3).

Phylogenetic analysis was able to confidently predict two subclade topologies and was well supported by bootstrap analysis, but basal branching patterns couldn't be unambiguously estimated. In network, we did not find the ancestry of the haplotypes (Figures 2 and 3). Thus, we suggest that there was no obvious phylogeographic pattern within Amur grayling. Pairwise $\mathrm{F}_{\mathrm{ST}}$ comparisons test among 12 populations showed that the differences were irrelevant to their distributions (Table 5).

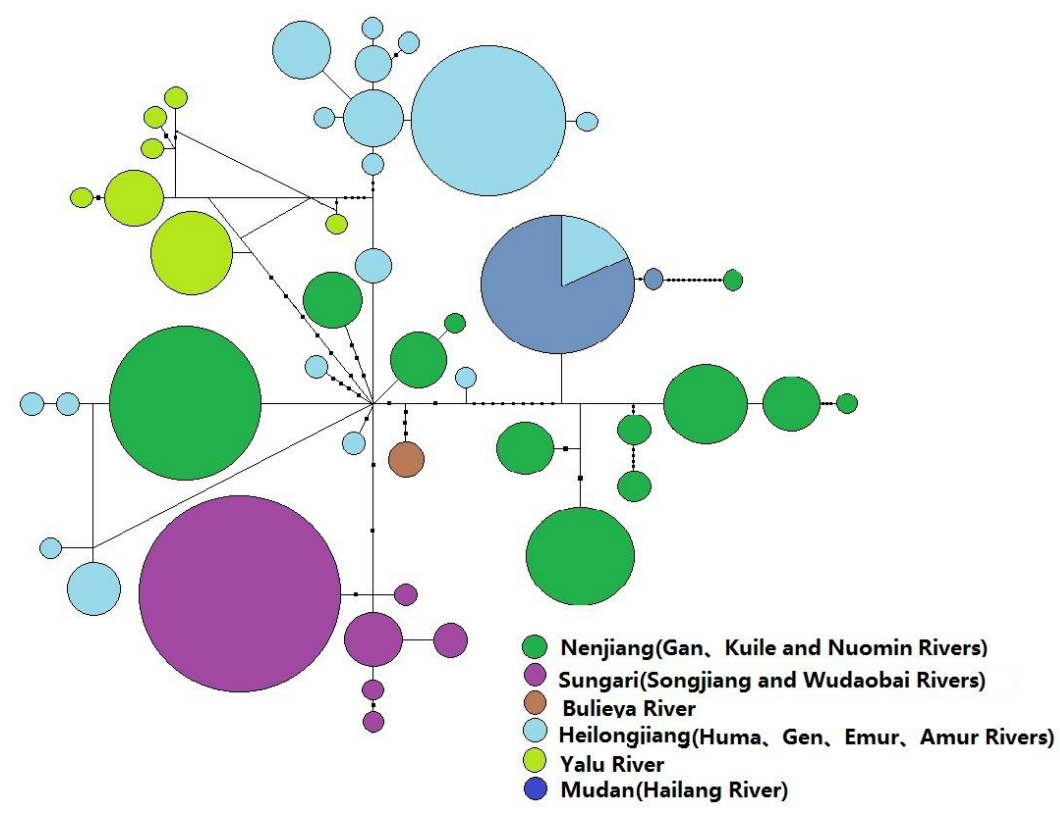

Figure 3. Parsimony haplotype networks for Amur graying.Haplotypes are colour coded based on sampling locality in the map. Circles are sized in proportion to the number of individuals with that haplotype. 
Table 2. 64 variable sites of the D-loop region in Amur grayling without considering the alignment gaps. Dots (.) indicate nucleotide identity

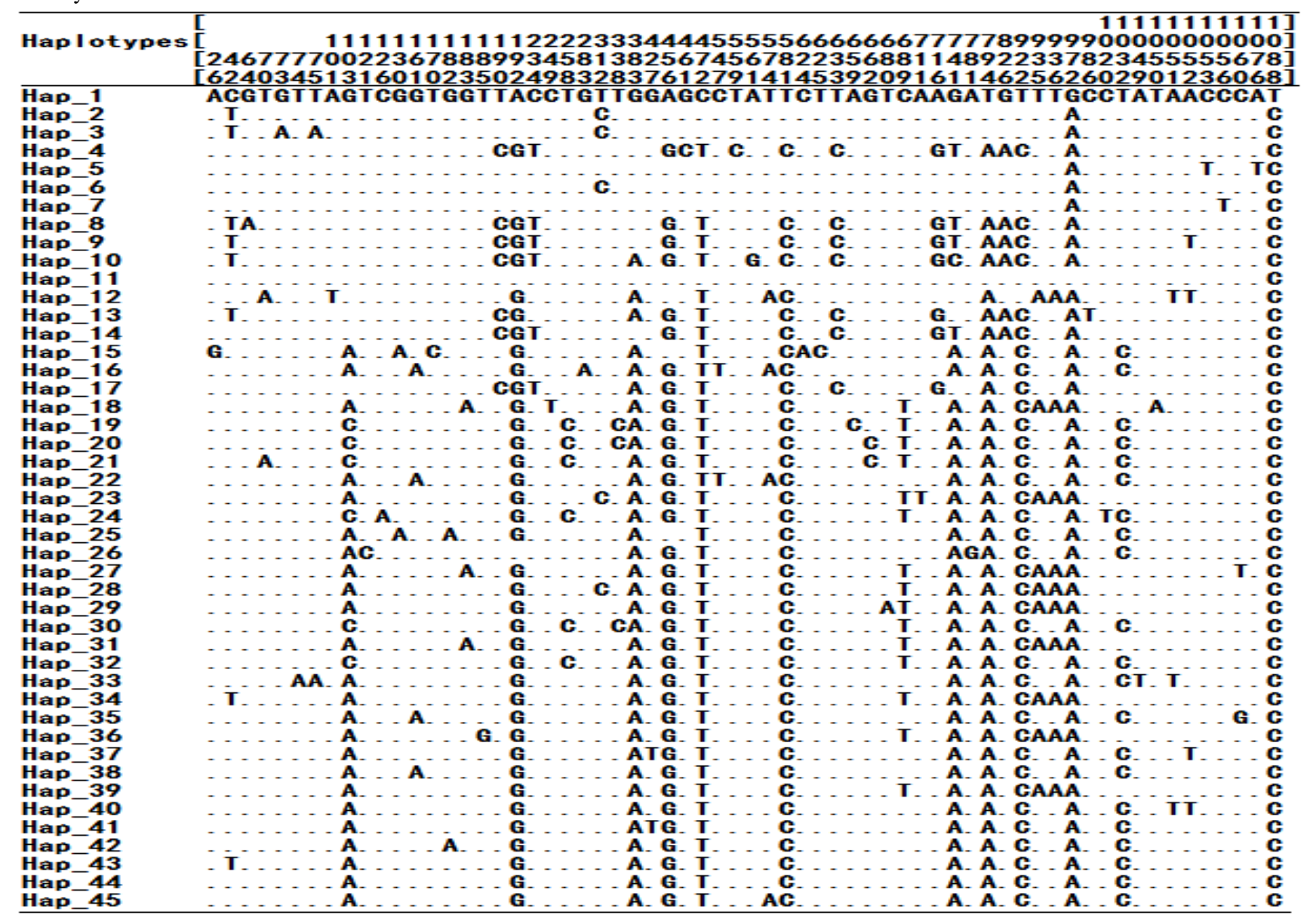

AMOVA analysis revealed that there were significant subdivisions within populations and among basins of Amur grayling and significant genetic variance was also found among populations, $12.01 \%$ of the genetic variance was found among populations (Table 6), which provided evidences that the high level of population structure was related to the hydrological pattern.

\section{Demographic analysis}

Values for Fu and Li's D* and Fu's Fs in Amur grayling populations from Amur, Nenjiang, Sungari, Yalu and Mudan Rivers appeared negative but not significant (Table 7), indicating that Amur grayling populations in the Amur drainage were in a process of dynamic balance. The shape of the mismatch distribution for Amur graying was a ragged multimodal curve in the populations from these rivers, which supports the above result.

\section{DISCUSSION}

\section{Phylogenetic analysis}

Molecular based investigations of T. grubii in the Amur basin continued to reveal extensive genetic variation. The
Maximum Parsimony tree depicted two highly distinct clades $(100 \%$ bootstrap support), marked A and B respectively, one representing Yalu and Nenjiang Rivers (A), and the other representing other branch rivers of Amur (B) (Figure 2, MP tree shown). Bayesian method analyses also resulted in almost identical tree topologies, and different populations from Amur River were distinct haplotype groups but with low bootstrap support $(<50 \%)$. There was geographical structure among haplotypes related to different rivers (Figure 2), which was supported by network analysis (Figure 3).

There existed deep divergence between T. grubii in the Nenjiang and Yalu Rivers (Clade A) and T. grubii found in the remaining Amur drainage populations (Clade B). Nenjiang River was the source of the Liao River from the Pliocene to the Pleistocene of Quaternary, southward into Bo Sea, reaching to Zeya River basin within the borders of the former Soviet Union. In middle Early Pleistocene of Quaternary, Xiaoxing an Mountain emerged and became the watershed of Amur and Sungari River, separating Nenjiang River and Zeya River. Later, at the end of Early Pleistocene or the start of Middle Pleistocene, SongLiao watershed emerged, which separated Nenjiang River and Liao River. 
Table 3. Summary of mtDNA control region haplotype distributions

\begin{tabular}{|c|c|c|c|c|c|c|c|c|c|c|c|c|c|}
\hline Haplotypes & $\begin{array}{c}\text { Yalu } \\
\text { R.. }\end{array}$ & $\begin{array}{l}\text { Huma } \\
\text { R. }\end{array}$ & $\begin{array}{c}\text { Wudaobai } \\
\text { R.. }\end{array}$ & $\begin{array}{c}\text { Songjiang } \\
\text { R.. }\end{array}$ & $\begin{array}{c}\text { Kuile } \\
\text { R.. }\end{array}$ & $\begin{array}{c}\text { Nuomin } \\
\text { R.. }\end{array}$ & $\begin{array}{c}\text { Gan } \\
\mathrm{R}\end{array}$ & $\begin{array}{c}\text { Emur } \\
\text { R.. }\end{array}$ & $\begin{array}{c}\text { Hailang } \\
\text { R.. }\end{array}$ & $\begin{array}{c}\text { Ing/Ono } \\
\text { R. }\end{array}$ & $\begin{array}{c}\text { Bureya } \\
\text { R. }\end{array}$ & $\begin{array}{c}\text { Gen } \\
\mathrm{R}\end{array}$ & Total \\
\hline$\overline{\text { F01 }}$ & & & & & & & 2 & & & & & & 2 \\
\hline F02 & & & & & & & 4 & & & & & & 4 \\
\hline F03 & & & & & & 1 & & & & & & & 1 \\
\hline F04 & 1 & & & & & & & & & & & & 1 \\
\hline F05 & & & & & 2 & & 1 & & & & & & 3 \\
\hline F06 & & & & & & & 5 & & & & & & 5 \\
\hline F07 & & & & & & & 6 & & & & & & 6 \\
\hline F08 & 1 & & & & & & & & & & & & 1 \\
\hline F09 & 1 & & & & & & & & & & & & 1 \\
\hline F10 & 1 & & & & & & & & & & & & 1 \\
\hline F11 & & & & & & 2 & & & & & & & 2 \\
\hline F12 & & & & & 1 & & & & & & & & 1 \\
\hline F13 & 1 & & & & & & & & & & & & 1 \\
\hline F14 & 3 & & & & & & & & & & & & 3 \\
\hline F15 & & & & & & & & & & & 2 & & 2 \\
\hline F16 & & 1 & & & & & & & & & & & 1 \\
\hline F17 & 4 & & & & & & & & & & & & 4 \\
\hline F18 & & 1 & & & & & & & & & & & 1 \\
\hline F19 & & & & 2 & & & & & & & & & 2 \\
\hline F20 & & & & 1 & & & & & & & & & 1 \\
\hline F21 & & & & 1 & & & & & & & & & 1 \\
\hline F22 & & 1 & & & & & & & & & & & 1 \\
\hline F23 & & 1 & & & & & & & & & & & 1 \\
\hline F24 & & & & 1 & & & & & & & & & 1 \\
\hline F25 & & & & & & & & & & 1 & & & 1 \\
\hline F26 & & & & & & & & & 3 & & & & 3 \\
\hline F27 & & 1 & & & & & & & & & & & 1 \\
\hline F28 & & 2 & & & & & & 3 & & & & 2 & 7 \\
\hline F29 & & & & & & & & & & 3 & & & 3 \\
\hline F30 & & & & 3 & & & & & & & & & 3 \\
\hline F31 & & 2 & & & & & & & & & & & 2 \\
\hline F32 & & & 8 & & & & & & & & & & 8 \\
\hline F33 & & & & & & & & & & & & 1 & 1 \\
\hline F34 & & & & & & & & & & 1 & & & 1 \\
\hline F35 & & 1 & & & & & & & & & & & 1 \\
\hline F36 & & & & & & & & & & 1 & & & 1 \\
\hline F37 & & & & & & & & & 1 & & & & 1 \\
\hline F38 & & 3 & & & & & & & & & & & 3 \\
\hline F39 & & 2 & & & & & & & & & & 1 & 3 \\
\hline F40 & & & & & & & & & 1 & & & & 1 \\
\hline F41 & & & & & & & & & 3 & & & & 3 \\
\hline F42 & & & & & & & & 1 & & & & & 1 \\
\hline F43 & & & & & & & & & & 2 & & & 2 \\
\hline F44 & & 1 & & & & & & & 4 & 2 & & & 7 \\
\hline F45 & & & & & & & & & 7 & & & & 7 \\
\hline Total & 12 & 16 & 8 & 8 & 3 & 3 & 18 & 4 & 19 & 10 & 2 & 4 & 107 \\
\hline
\end{tabular}

At the end of Middle Pleistocene, the Nenjiang River was forced to u-turn and change its route eastward to flow to the Sungari River, and then into Amur (Liu, 1958; Berg, 1972). Yalu River is not one of the rivers of the Amur drainage; there exists a geographical distance between these two drainages, which is supported by the greater genetic difference between populations from the Yalu River and Amur drainages. Moreover, since the Sungari River and Yalu River both originate in the Changbai Mountain, we inferred that the Yalu River once connected with the Amur drainage (such as Nenjiang River). Maybe later a geographic event such as the formation of Changbai Mountain caused the Yalu River and the Amur drainage to disconnect from each other causing the Yalu River population to split from the Sungari River population. $\mathrm{F}_{\mathrm{ST}}$ values also indicate that there was no correlation between genetic differentiation and geographic distance.

The pattern and depth of genetic diversity among these forms support a complex phylogeographical history, probably stemming from major palaeohydrological shifts in drainage patterns during Pleistocene glaciations (Grosswald, 1998). The sympatric lineages in Northeast China, in 
Table 4. Descriptive statistics of Amur grayling based on control region sequence data

\begin{tabular}{|c|c|c|c|c|c|c|}
\hline Population & $\mathrm{N}$ & $\mathrm{H}$ & $\mathrm{h}$ & $\mathrm{S}$ & $\mathrm{K}$ & $\pi$ \\
\hline Sungari river & 16 & 6 & $0.733 \pm 0.108$ & 6 & 1.341 & $0.0012 \pm 0.0013$ \\
\hline Wudaobai river & 8 & 1 & $0.000 \pm 0.000$ & 0 & 0.000 & $0.0000 \pm 0.0000$ \\
\hline Songjiang river & 8 & 5 & $0.857 \pm 0.108$ & 6 & 2.036 & $0.0019 \pm 0.0013$ \\
\hline Nenjiang river & 24 & 9 & $0.869 \pm 0.035$ & 21 & 3.315 & $0.0035 \pm 0.0009$ \\
\hline Gan river & 18 & 5 & $0.791 \pm 0.052$ & 16 & 4.739 & $0.0043 \pm 0.0025$ \\
\hline Nuomin river & 3 & 2 & $0.667 \pm 0.314$ & 5 & 3.333 & $0.0030 \pm 0.0026$ \\
\hline Kuile river & 3 & 2 & $0.667 \pm 0.314$ & 16 & 10.667 & $0.0097 \pm 0.0076$ \\
\hline Mudan river & 19 & 6 & $0.807 \pm 0.059$ & 7 & 1.988 & $0.0018 \pm 0.0003$ \\
\hline Hailang river & 19 & 6 & $0.807 \pm 0.059$ & 10 & 3.088 & $0.0028 \pm 0.0017$ \\
\hline Yalu river & 12 & 7 & $0.864 \pm 0.079$ & 11 & 3.303 & $0.0040 \pm 0.0024$ \\
\hline Amur river & 34 & 22 & $0.924 \pm 0.075$ & 28 & 4.869 & $0.0048 \pm 0.0050$ \\
\hline Huma river & 16 & 11 & $0.950 \pm 0.036$ & 17 & 5.108 & $0.0046 \pm 0.0027$ \\
\hline Emur & 4 & 2 & $0.500 \pm 0.265$ & 7 & 3.500 & $0.0032 \pm 0.0024$ \\
\hline Ingoda/Onon river & 10 & 6 & $0.889 \pm 0.075$ & 12 & 4.889 & $0.0045 \pm 0.0027$ \\
\hline Gen river & 4 & 3 & $0.833 \pm 0.222$ & 10 & 5.167 & $0.0047 \pm 0.0034$ \\
\hline Bureya river & 2 & 1 & $0.000 \pm 0.000$ & 0 & 0.000 & $0.0000 \pm 0.0000$ \\
\hline Entire requion (all samples) & 107 & 45 & $0.972 \pm 0.005$ & 64 & 8.789 & $0.0081 \pm 0.0004$ \\
\hline
\end{tabular}

$\mathrm{N}=$ Number of individuals; $\mathrm{H}=$ Number of haplotypes; $\mathrm{S}=$ Number of segregating sites; $\mathrm{h}=$ Gene diversity ( \pm Standard deviation); $\mathrm{K}=$ Average number of differences; $\pi=$ Nucleotide diversity ( \pm Standard deviation).

particular, with a mean control region sequence divergence of $12.01 \%$, strongly suggested an allopatric origin with secondary contact and complete geographic isolation. Such deep divergence in sympatry is rare among phylogeographical studies of widely distributed freshwater fishes (Avise, 2000). This supports the existence of major historical fragmentation events of the present-day Amur River (Froufe, 2002). It seems plausible that the basin has undergone multiple events of hydrological fragmentation and re-union of tributaries, promoting allopatric speciation in Thymallus.

From the haplotypes shared between rivers, except Amur River with Mandan River and Amur River with
Nenjiang River, we didn't detect gene flow between different populations. In the reduplicative climate changes, species range shrunk, and species retreated to one or more shelters (Broccoli and Manabe, 1992; Hewitt, 1996). Huma River had the most haplotype diversity. We infer that perhaps the Huma River was the shelter area for Amur grayling when the palaeoclimate changed. Our data supports a relatively recent hydrological mixing of major river drainage systems in the Amur basin, as shared haplotypes had already been demonstrated.

\section{Population genetic structure and phylogeography}

Our results revealed low nucleotide diversity $(\pi=$

Table 5. Pairwise FST values among Amur grayling populations

\begin{tabular}{|c|c|c|c|c|c|c|c|c|c|c|c|c|}
\hline & Gan & Nuomin & Kuile & Yalu & Bureya & Huma & Amur & Emur & Gen & Songjiang & Wudaobai & Hailang \\
\hline$\overline{\text { Gan }}$ & 0.0000 & & & & & & & & & & & \\
\hline Nuomin & $0.2874 *$ & 0.00000 & & & & & & & & & & \\
\hline Kuile & $0.2927 *$ & 0.3824 & 0.0000 & & & & & & & & & \\
\hline Yalu & $0.7482 *$ & $0.7422 *$ & $0.6891 *$ & 0.0000 & & & & & & & & \\
\hline Bureya & $0.7863^{*}$ & 0.8778 & 0.6547 & $0.7556^{*}$ & 0.0000 & & & & & & & \\
\hline Huma & $0.7330 *$ & $0.7147 *$ & $0.6500 *$ & $0.6197 *$ & $0.5665^{*}$ & 0.0000 & & & & & & \\
\hline Amur & $0.7203 *$ & $0.7208 *$ & $0.6151 *$ & $0.6181 *$ & $0.5635^{*}$ & 0.0514 & 0.0000 & & & & & \\
\hline Emur & $0.7506^{*}$ & $0.7888 *$ & $0.6339 *$ & $0.6667 *$ & 0.7519 & 0.0262 & 0.0979 & 0.0000 & & & & \\
\hline Gen & $0.7416^{*}$ & $0.7368 *$ & $0.5863 *$ & $0.6434 *$ & $0.6551 *$ & 0.0108 & 0.0650 & -0.1556 & 0.0000 & & & \\
\hline Songjiang & $0.8028 *$ & $0.8666^{*}$ & $0.7821 *$ & $0.7428 *$ & $0.8375^{*}$ & $0.4810^{*}$ & $0.5057 *$ & $0.6554 *$ & $0.6014 *$ & 0.0000 & & \\
\hline Wudaobai & $0.8282 *$ & $0.9550 *$ & $0.8628 *$ & $0.7943^{*}$ & $1.0000 *$ & $0.5439 *$ & $0.5980^{*}$ & $0.8331 *$ & $0.7642 *$ & $0.6122 *$ & 0.0000 & \\
\hline Hailang & $0.7630 *$ & $0.7974 *$ & $0.7293 *$ & $0.6853^{*}$ & $0.6578 *$ & $0.2916^{*}$ & $0.2508^{*}$ & $0.4791 *$ & $0.4443 *$ & $0.5838 *$ & $0.6557 *$ & 0.0000 \\
\hline
\end{tabular}

Asterisks indicate significant values after Bonferroni correction. Amur represents Onon and Ingoda Rivers. 
Table 6. The results of AMOVA for Amur grayling D-loop estimated using $\Phi$-statistics

\begin{tabular}{lccccc}
\hline $\begin{array}{l}\text { Source of } \\
\text { variation }\end{array}$ & d.f. & $\begin{array}{c}\text { Sum of } \\
\text { squares }\end{array}$ & $\begin{array}{c}\text { Variance } \\
\text { components }\end{array}$ & $\begin{array}{c}\text { Percentage } \\
\text { of variation }\end{array}$ & $\begin{array}{c}\Phi \text {-statistics } \\
(\mathrm{p} \text {-value })\end{array}$ \\
\hline Among basins & 4 & 348.589 & 3.65684 & 57.22 & $\begin{array}{c}\Phi S T: 0.69227 * \\
(\mathrm{p}=0.000)\end{array}$ \\
$\begin{array}{l}\text { Among populations } \\
\text { wthin basins }\end{array}$ & 7 & 46.667 & 0.76759 & 12.01 & $\begin{array}{c}\Phi S \mathrm{C}: 0.28072 * \\
(\mathrm{p}=0.000)\end{array}$ \\
$\begin{array}{l}\text { Within populations } \\
\text { Total }\end{array}$ & 95 & 186.838 & 1.96672 & 30.77 & $\begin{array}{c}\Phi \mathrm{CT}: 0.57217 * \\
(\mathrm{p}=0.000)\end{array}$ \\
\hline
\end{tabular}

$* \mathrm{p}<0.01$

$0.0081 \pm 0.0004)$ and high haplotype diversity ( $\mathrm{h}=$ $0.972 \pm 0.005$ ) in Amur grayling (Table 4), which could reflect a short evolutionary history of the population. This scenario was also supported by the different branching among haplotypes in the phylogenetic tree and the "starlike" shaped network (Figures 2 and 3 ) as well as demographic history analysis. There was a high proportion of genetic variation between different rivers of the Amur basin (ФSC: $0.28072 *$ ), which suggested there was significant genetic differentiation within Amur grayling populations, with few haplotypes shared among rivers. This unique genetic structure was related to the evolution history and biological characteristics of Amur grayling. Amur grayling have unique life history characteristics, such as the limited dispersal abilities and a strong retracing of river spawning (Northcote, 1995; Nykänen et al., 2005; Gönczi 2008). These biological characteristics easily led to familial populations and limited the level of gene flow between populations and resulted in significant genetic variation between geographical populations. Moreover, habitat fragmentation could also cause genetic differences between different populations. The result of the nested clade analysis also indicated there may exist habitat fragmentation and restricted gene flow in the history of the Amur grayling population.

Significant fine-scale population structure in Amur grayling was found, and it appeared that there were some genetic mechanisms promoting population isolation (Gross et al., 2001; Sušnik et al., 2001), which is strengthened by the comparative work of Froufe et al. (2003). Our MSN network showed that haplotypes were geographically structured while tests of AMOVA indicated that $57.22 \%$ of the genetic variance was due to between basin differences, and $30.77 \%$ within population variation, which was further supported by significant evidence of genetic differentiation from $\mathrm{F}_{\mathrm{ST}}$ statistics. Only $12.01 \%$ of the genetic variance was due to among populations within basins.

The haplotypes distribution of Amur grayling displayed distinctly regional concentration, haplotypes from the mitochondrial clades showed a river related genetic structure among all populations sampled across Amur basin except the individuals from Emur and Huma Rivers and significant genetic differentiation between each of these populations. These results were also reflected in the distribution of haplotypes in the MSN network, in which the haplotypes formed a river related network. Bayesian clustering of genotypes also revealed clear subdivision except for the Amur populations.

Mismatch distribution and the no significant Fu and Li's $\mathrm{D}$ and Fu's Fs values indicated that population dynamics of Amur graying were complicated. We couldn't explain this process with only one demographic expansion or contraction. On account of changes in interconnectivity within and between drainages and effects of paleoclimate, Amur graying experienced complicated history dynamic, but each population appeared dynamic balance.

\section{Conservation and management strategy of Amur grayling}

Although the genetic diversity level of Amur grayling populations is high, fishery resources face endangered status, so conservation and management work is urgently required. The significant differences of Amur grayling between Nenjiang River, Yalu River and other populations in the Amur drainage indicates a retained low gene flow. According to the result of AMOVA and the unique life history characteristic of grayling, it is necessary to treat populations in Nenjiang, Yalu River, Sungari River and

Table 7. Fu and Li's D* and Fu's Fs test for control region sequences

\begin{tabular}{lllllc}
\hline & Heilongjiang & Mudan & Sungari & Nenjiang & \multicolumn{1}{c}{ Yalu } \\
& $\mathrm{R}$ & $\mathrm{R}$ & $\mathrm{R}$ & $\mathrm{R}$ & $\mathrm{R}$ \\
\hline$D$ & -1.295 & -0.566 & -0.416 & -1.531 & -0.718 \\
$F s$ & -14.55 & -3.51 & -3.78 & -3.33 & -3.18 \\
\hline
\end{tabular}

Asterisks indicate significant values, $\mathrm{p}<0.01$. 
Amur River as different so that conservation management units can conserve the peculiar genetic diversity. So far, the decrease of the habitat and human activities are the main factors threating Amur grayling populations rather than the decrease of genetic diversity. Therefore, we suggest the work of conservation focuses on restoring and protecting the habitat in future.

\section{ACKNOWLEDGEMENTS}

This work was funded by Key Laboratory of Ecology of Rare and Endangered Species and Environmental Protection (Guangxi Normal University), Ministry of Education, China (1002K007), Guangdong Bureau of Sciences and Technology (2010B060200034) and Central Public-interest Scientific Institution Basal Research Fund of China (2007HSYZX-ZH-24).

\section{REFERENCES}

Antonov, A. L., B. A. Voronov, V. M. Sapayev and E. V. Adnagulov. 1996. Bassein r. Annui - perspektivnaya territoriya visokogo prirodookhrannogo statusa. 3-D Far Eastern Conference Devoted to Reservation, pp. Dalnauka Press, Vladivostock 15-16.

Avise, J. C. 2000. Phylogeography: The History and Formation of Species. Harvard University Press, Cambridge, MA, USA.

Bailey, N. W., D. T. Gwynne and M. G. Ritchie. 2007. Dispersal differences predict population genetic structure in Mormon crickets. Mol. Ecol. 16:2079-2089.

Broccoli, A. J. and S. Manabe. 1992. The effects of orography on midlatitute northern hemisphere dry climates. J. Clim. 5:11811201.

Dybowski, B. N. 1869. Vorlaufige Mittheilungen über die Fischfauna des Ononflusses and des Ingoda in Transbaicalien. Verh. Zool. Bot. Ges. Vien 19:209-222.

Excoffier, L., P. E. Smouse and J. M. Quattro. 1992. Analysis of molecular variance inferred from metric distances among DNA haplotypes: applications to human mitochondrial DNA restriction data. Genetics 131:479-491.

Froufe, E., S. Alekseyev, I. Knizhin, P. Alexandrino and S. Weiss. 2003. Comparative phylogeography of salmonid fishes (Salmonidae) reveals late to post-Pleistocene exchange between three now-disjunct river basins in Siberia. Divers. Distrib. 9:269-282.

Froufe, E., I. Knizhin, M. T. Koskinen, C. R. Primmer and S. Weiss. 2003a. Identification of reproductively isolated lineages of Amur grayling (Thymallus grubii Dybowski 1869): concordance between phenotypic and genetic variation. Mol. Ecol. 12:2345-2355.

Froufe, E., S. Alekseyev, I. Knizhin, P. Alexandrino and S. Weiss. 2003b. Comparative phylogeography of salmonid fishes (Salmonidae) reveals late to post-Pleistocene exchange between three now-disjunct rivers basins in Siberia. Divers. Distrib. 9:269-282.

Fu, Y. X. 1997. Statistical tests of neutrality of mutations against population growth, hitchhiking and background selection.
Genetics 147:915-925.

Garcia-Ramos, G. and M. Kirkpatrick. 1997. Genetic models of adaptation and gene flow in peripheral population. Evolution 51:21-28.

Gönczi, A. P. 2008. A study of physical parameters at the spawning sites of the european grayling (Thymallus thymallus L.). Regulated Ricers: Res. Manage. 3(1):221-224.

Gross, R., R. Kühn, M. Baars, W. Schröder, H. Stein and O. Rottman. 2001. Genetic differentiation of European grayling populations across the Main, Danube and Elbe drainages in Bavaria. J. Fish Biol. 58:264-280.

Grosswald, M. G. 1998. New approach to the ice age paleohydrology of northern Eurasia. In: Paleohydrology and Environmental Change (Ed. G. Benito, V. R. Baker and K. J. Gregory). pp Wiley, Chichester 199-214.

Hewitt, G. 2000. The genetic legacy of the Quaternary ice ages. Nature 405:907-913.

Hewitt, G. M. 1996. Some genetic consequences of ice ages, and their role in divergence and speciation. Biol. J. Linn. Soc. 58:247-276.

Hewitt, G. M. 2004. Genetic consequences of climatic oscillations in the Quaternary. Philos. Trans. R. Soc. Biol. Sci. 359:183195.

Huelsenbeck, J. P. and F. Ronquist. 2001. MrBayes: Bayesian inference of phylogeny. Bioinformatics 17:754-755.

Kamal, M. I., A. N. Richard and G. M. Hewitt. 1996. Spatial patterns of genetic variation generated by different forms of dispersal during range expansion. Heredity 77:282-291.

Kark, S., P. U. Philip, U. N. Safriel and E. Randi. 1999. Conservation priorities for chukar partridge in Israel based on genetic diversity across an ecological gradient. Conserv. Biol. 13:542-552.

Koskinen, M. T., I. Knizhin, C. R. Primmer, C. Schlötterer and S. Weiss. 2002. Mitochondrial and nuclear DNA phylogeography of Thymallus spp. (grayling) provides evidence of ice-age mediated environmental perturbations in the world's oldest body of fresh water, Lake Baikal. Mol. Ecol. 11:2599-2611.

Kumar, S., K. Tamura, I. B. Jakobsen and M. Nei. 2001. Mega2: molecular evolutionary genetics analysis software. Bioinformatics 17:1244-1245.

Liu Peixin. 1958. Nature and geography in Northeast China. Shanghai, Xinzhi Publishing House 5-15.

McGlashan, D. J.and J. M. Hughes. 2000. Reconciling patterns of genetic variation with stream structure, earth history and biology in the Australian freshwater fish Craterocephalus stercusmuscarum (Atherinidae). Mol. Ecol. 9:1737-1751.

Nei, M. 1986. Molecular evolutionary genetics. Columbia University Press, NY, USA.

Nicolsigy, T. B. (Gao X translated). 1960. Fishes of the Heilongjiang valley, Science Press.

Northcote, T. G. 1995. Comparative biology and management of Arctic and European grayling (Salmonidae, Thymallus). Rev. Fish Biol. Fish. 5:141-194.

Nykänen, M., A. Huusko and A. Mäki-Petäys. 2005. Seasonal changes in the habitat use and movements of adult European grayling in a large subarctic river. J. Fish Biol. 58:506-519.

Posada, D. and K. A. Crandall. 1998. Modeltest: Testing the model of DNA substitution. Bioinformatics 14:817-818.

Sušnik, S., A. Snoj and P. Dovc. 2001. Evolutionary 
distinctiveness of grayling (Thymallus thymallus) inhabiting the Adriatic river system, as based on mtDNA variation. Biol. J. Linn. Soc. 74:375-385.

Proctor, M. F., B. N. Mclellan, C. Strobeck and R. M. R. Barclay. 2004. Gender-specific dispersal distances of grizzly bears estimated by genetic analysis. Can. J. Zool. -Revue Canadienne De Zoologie 82:1108-1118.

Ramos-Onsins, S. E. and J. Rozas. 2002. Statistical properties of new neutrality tests against population growth. Mol. Biol. Evol. 19:2092-2100.

Rogers, A. R. 1995. Genetic evidence for a Pleistocene population explosion. Evolution 49:608-615.

Rogers, A. R. and H. C. Harpending. 1992. Population growth makes waves in the distribution of pairwise genetic differences. Mol. Biol. Evol. 9:552-569.

Rozas, J., J. C. Sánchez-DelBarrio, X. Messeguer and R. Rozas. 2003. DNASP, DNA polymorphism analyses by the coalescent and other methods. Bioinformatics 19:2496-2497.
Schneider, S., D. Roessli and L. Excoffier. 2000. Arlequin, Version 2.Genetics and Biometry Laboratory, Department of Anthropology,University of Geneva, Geneva.

Swofford, D. L. 2001. PAUP ver 4.0.b3a. Phylogenetic Analysis Using Parsimony and Other Methods. Sunderland, MA:Sinauer Associates.

Taggart, J. B., R. Hynes, P. A. Prodohl and A. Ferguson. 1992. A simplified protocol for routine total DNA isolation from Salmonid fishes. J. Fish Biol. 40:963-965.

Uiblein, F., A. Jagsch and W. Honsig-Erlenburg. 2001. Status, habitat use, and vulnerability of the European grayling in Austrian water. J. Fish Biol. 59:223-247.

Weiss, S., I. Knizhin, A. Kirillov and E. Froufe. 2006. Phenotypic and genetic differentiation of two major phylogeographical lineages of arctic grayling Thymallus arcticus in the Lena River, and surrounding Arctic drainages. Biol. J. Linn. Soc. 88: 511-525. 